\title{
Biostratigraphy of the Konkian (Middle Miocene of the Eastern Paratethys) deposits of Southern Ukraine based on foraminifera
}

\author{
Yuliia Vernyhorova \\ National Academy of Sciences of Ukraine, Institute of Geological Sciences, Department of stratigraphy and palaeontology of the Cenozoic deposits \\ O. Honchar str., 55 b, Kyiv, 01601 Ukraine; (july.vern@gmail.com)
}

doi: $10.4154 / g c .2018 .18$

Article history:

Manuscript received January 30, 2018 Revised manuscript accepted September 18, 2018 Available online October 24, 2018

Keywords: Foraminifera, Mollusca Biostratigraphy, Palaeocology, Konkian, Upper Badenian, Eastern Paratethys, Southern Ukraine

\begin{abstract}
The Konkian (Middle Miocene) foraminiferal assemblages and molluscs from five Wells situated in Southern Ukraine were studied in order to correlate the palaeoecology and biostratigraphy of the coeval palaeobasins with different environmental conditions. The article contains comprehensive analysis of controversial issues of the Konkian stratigraphy of the Eastern Paratethys and additional keys for determination of Konkian development phases by foraminifera and molluscs. Five stenohaline normal-marine, two euryhaline and one mixed foraminiferal assemblage were identified in different levels in the investigated wells with the analysis of their accordance to different molluscs assemblages. The study defines an isochronous foraminiferal assemblage for some wells, suggests a palaeoecological and stratigraphic reconstuction of the middle Miocene sediments in the Eastern Black Sea Region and recognizes two models of development of the Konkian foraminiferal assemblages. These models show the differences between environmental conditions in the shallow-water basin of the Eastern Black Sea Region and deeper water basin of the Kerch Peninsula at that time. While the Eastern Black Sea Region was influenced by frequent and abrupt changes in environmental conditions during almost all Konkian time, a relatively deeper basin of the Kerch Peninsula had a successive phase. The late Konkian time created similar depositional conditions for both basins.
\end{abstract}

\section{INTRODUCTION}

The Konkian is the Middle Miocene stage of the Eastern Paratethys that corresponds to the NN6-NN7 Nannoplankton Zone (NEVESSKAYA et al., 2005), to the Serravallian of the Global Time Scale and to the upper Badenian (Kosovian) of the Central Paratethys (HILGEN et al., 2012). The Karaganian/Konkian boundary is dated at $13.4 \mathrm{Ma}$, and the Konkian/Sarmatian boundary is dated at $12.65 \mathrm{Ma}$ (PALCU et al., 2017). The Konkian (upper Badenian) time is characterized by a marine transgression which reactivated connections between the Central and Eastern Paratethys. The preceding Karaganian time was characterized by euryhaline conditions which correspond to the Badenian Salinity Crisis in the middle Badenian of Central Paratethys (e.g. MURATOV \& NEVESSKAYA, eds., 1986; PERYT, 2006). After the Konkian (upper Badenian), the Sarmatian basin was characterized by palaeoenvironmental changes and the appearance of an endemic fauna in the Eastern and Central Paratethys. (e.g. MURATOV \& NEVESSKAYA, eds., 1986; NEVESSKAYA et al., 2005; HILGEN et al., 2012).

The aim of this study is to understand how the foraminiferal assemblages developed and to show the differences between the shallow-water and deeper water basins in the Konkian. The results are discussed in the context of temporal and spatial changes of foraminiferal species diversity and presented together with the analysis of molluscs as an additional group in the various Konkian facies of the Southern Ukraine.

\section{THE KONKIAN REGIONAL STAGE OF THE EASTERN PARATETHYS}

\subsection{Peculiarities of the Konkian stratigraphy of the Eastern Paratethys}

The first stratigraphic studies of the Neogene of the Eastern Paratethys were based on identification of mollusc assemblages. If certain species of molluscs were traced in sections, then these deposits were defined as the same age and such mollusc associations were identified as "Beds with molluscs" (e.g. ANDRUSOV, 1917; ARKHANGUELSKY, 1930). Several "Beds with molluscs" were determined in the Konkian deposits: Beds with Venus konkensis in the Northern Black Sea Region of the Southern Ukraine (SOKOLOW, 1899), were named later as the Veselyanka Beds by MERKLIN (1953); the Pholadidae Beds on the Kerch Peninsula of the Southern Ukraine (ANDRUSOV, 1917); the Kartvel Beds in Georgia (DAVITASHVILY, 1930); the Sartagan Beds in Transcaspian (ZHIZHCHENKO, 1937a, b). The Kartvel Beds are characterized (Fig. 1) by Pholadidae (Barnea pseudoustjurtensis BOGATCHEV, B. ustjurtensis (EICHWALD), $B$. kubanica (ZHIZHCHENKO) B. scrinia (BOGATSCHEV) etc.); the Sartagan Beds are defined as deposits with a rich marine stenohaline Konkian mollusc fauna; the Veselyanka Beds are defined as deposits with euryhaline Konkian molluscs (MERKLIN, 1953; VERESHAGIN \& MIRONOVA, 1982; MURATOV \& NEVESSKAYA, eds., 1986). Later, such Beds with molluscs were found in the Konkian of other areas of the Eastern Paratethys (e.g. VARENTSOV, 1950; MERKLIN, 1953; MURATOV \& NEVESSKAYA, eds., 1986). Shallow-water Konkian deposits often comprise Beds with Ervilia trigonula SOKOLOV or Beds with E. trigonula and Barnea pseudoustjurtensis, B. kubanica in the Southern Ukraine (MOLYAVKO, 1960; BARG, 1969). Therefore, they were called the "Ervilia-Pholadidae Beds" and were also considered as Kartvel Beds (BARG, 1969).

The age of the Kartvel Beds has been under discussion. These Beds were defined as belonging to both the Karaganian and the Konkian regiostages based on the mollusc species composition (Pholadidae) (ZHIZHCHENKO, 1937a, 1937b; BURIAK, 1965). They were also considered as the final stage of the Karaganian (SUDO, 1961; NEVESSKAYA et al., 2005) or were 
determined as the individual Kartvelian regiostage (ZHGENTI, 1976; ILYINA, 2000; ZHGENTI \& MAISSURADZE, 2016).

The presence of typical Konkian species of foraminifera (Varidentella reussi sartaganica KRASHENINNIKOV, Nodobaculariella konkensis BOGDANOWICZ, Nonion tauricus KRASHENINNIKOV, Reussella spinulosa (REUSS), Cassidulina bulbiformis KRASHENINNIKOV, Discorbis kartvelicus KRASHENINNIKOV, D. supinus KRASHENINNIKOV etc.) and ostracods (Leptocythere distenta SCHNEIDER, Loxoconcha spongiosa LJULJEV, Trachyleberis lascarevi SCHNEIDER etc.) in the Kartvel Beds is a sufficient basis to determine them as the Konkian regiostage (Fig. 1) (KRASHENINNIKOV, 1959; BARG \& IVANOVA, 2000; KRASHENINNIKOV et al., 2003; BARG \& STEPANIAK, 2003; BONDAR, 2004; PRISYAZHNYUK et al., 2007; GOLOVINA et al., 2009; VERNIGOROVA, 2009; IVANOVA, 2012; VERNYHOROVA, 2014, 2015a, b, 2016).

The Konkian age of the Sartagan Beds, was confirmed not only on the basis of molluscs but also by normal-marine assemblages of Konkian foraminifera (Fig. 1) such as Quinqueloculina minakovae ukrainica DIDKOWSKI, Varidentella reussi sartaganica, Nodobaculariella konkensis, N. didkowskii BOGDANOWICZ, Articulina vermicularis BOGDANOWICZ, Melonis soldanii (ORBIGNY), Borelis melo (FICHTEL \& MOLL), Cassidulina bulbiformis, Discorbis kartvelicus, D. supinus, Reussella spinulosa, etc. (KRASHENINNIKOV, 1959; DIDKOVSKIY, 1959; DJANELIDZE, 1970) and the Konkian ostracods such as Trachyleberis semiornara LJULJEV, T. golubjatnikovi SCHNEIDER, $T$. lascarevi, Leptocythere distenta, Loxoconch a spongiosa, Aglaiocypris konkensis SCHNEIDER, Aurila similis (REUSS) etc. (BARG \& STEPANIAK, 2003; BONDAR, 2004; PRISYAZHNYUK et al., 2007).

The Konkian age of the Veselyanka Beds, except for molluscs, is also confirmed by euryhaline assemblages of Konkian foraminifera (Fig. 1) such as Nonion tauricus KRASHENINNIKOV, Elphidium farsiensis KRASHENINNIKOV, E. horridum BOGDANOWICZ, etc. (KRASHENINNIKOV, 1959; DIDKOVSKIY, 1959; DJANELIDZE, 1970) and the Konkian ostracods (BARG \& STEPANIAK, 2003; BONDAR, 2004; PRISYAZHNYUK et al., 2007). According to the recent research on the Konkian/Sarmatian boundary in Georgia, the Sarmatian age was suggested for the Veselianka Beds. This conclusion was drawn from a comparison of foraminiferal assemblages from the Veselianka Beds with those from the Sartagan Beds and the lower Sarmatian deposits (KOIAVA et al., 2016). However, these foraminiferal data were not consistent with other palaeontological data (e.g. molluscs, ostracods) from the Konkian deposits which suggested a Konkian age for the Veselianka Beds (e.g. MERKLIN, 1953; MURATOV \& NEVESSKAYA, eds., 1986).

The Konkian regiostage was subdivided into three substages: Kartvel Beds, Sartagan Beds and Veselyanka Beds by MERKLIN (1953). However, there are researchers who do not support Merklin's point of view since the Konkian sections in different areas of the Eastern Paratethys have different and irregular deposit patterns with various "Beds with molluscs" (VARENTSOV, 1950; BULEISHVILI, 1960; NOSOVSKIY, 1960; CHIKOVANI, 1964; BARG, 1969; 2008; PRISYAZHNYUK et al., 2007; VERNIGOROVA, 2008, 2009, 2012). Also, some sections may have several levels with the same type of fossiliferous beds, while in others some horizons of such beds are missing (review presented in VERNIGOROVA, 2009). In addition, the Konkian deposits in Southern Ukraine comprise molluscs or foraminiferal assemblages with both normal-marine and euryhaline species (DIDKOVSKIY, 1959; MOLYAVKO, 1960; BARG, 1969; VERNIGOROVA, 2012).

As a result, researchers have two different opinions on the Konkian stratigraphy (Fig. 2). The first group considers that the Kartvel Beds, the Sartagan Beds and the Veselyanka Beds represent development phases in the Konkian basin (MERKLIN, 1953; BARG, 1993; BARG \& STEPANIAK, 2003; IVANOVA, 2012; STARIN, 2012; KOIAVA et al., 2016). They are therefore used in regional stratigraphy as the Konkian substages. The second group thinks that these beds can be associated with different environmental conditions which could appear at different times during the Konkian. So they are used as additional biostratigraphic subdivisions such as "Beds with fauna" (according to ZHAMOIDA, ed., 1977; TESLENKO, ed., 1997; GOZHYK, ed., 2012) in the local stratigraphy for the correlation of sections and palaeoenvironmental reconstructions of separate areas (VARENTSOV, 1950; BULEISHVILI, 1960; CHIKOVANI, 1964; BURIAK, 1965; PRISYAZHNYUK et al., 2007; VERNYHOROVA, 2014, 2015a, b, 2016).

Thus, today the terms the Kartvel Beds, the Sartagan Beds and the Veselyanka Beds are not clearly defined, as they can refer to stratigraphic horizons or palaeoecological conditions. So, there are problems in the case of their use for the correlation when it is necessary to compare deposits with the same names but they can have different semantic meanings. Therefore, it is possible to agree with the proposal of ILYINA (2000) not to divide the Konkian stage into several substages and not to call these units by their own names such as the Kartvel Beds, the Sartagan Beds and the Veselyanka Beds. However in the case when a researcher decides to divide the Konkian into substages it is proposed to use the terms: lower, middle and upper Konkian substages. If a re-

\begin{tabular}{|c|c|c|c|}
\hline & Kartvel Beds & Sartagan Beds & Veselyanka Beds \\
\hline Mollusca & $\begin{array}{l}\text { Barnea pseudoustjurtensis, } \\
\text { B. ustjurtensis, B. kubanica, } \\
\text { Envilia trigonula }\end{array}$ & $\begin{array}{c}\text { Konkian characteristic species; } \\
\text { predominance of stenohaline species } \\
\text { of genera: Chama, Chlamys, Anadara, } \\
\text { Turreitella, Spiratella etc. }\end{array}$ & $\begin{array}{l}\text { Konkian characteristic species; } \\
\text { predominance of euryhaline species } \\
\text { of genera: Parvivenus, Alvenius, } \\
\text { Parvicardium, Sandbergeria etc. }\end{array}$ \\
\hline Foraminifera & $\begin{array}{l}\text { Konkian characteristic species; } \\
\text { but there aren't specific and } \\
\text { characteristic species for } \\
\text { identification just these beds. } \\
\text { There are several assemblages } \\
\text { with different paleoecological } \\
\text { characteristics }\end{array}$ & $\begin{array}{l}\text { Konkian characteristic species; } \\
\text { predominance of stenohaline species } \\
\text { of genera: Lagena, Nodobaculariella, } \\
\text { Spirolina, Globulina, Virgulina, } \\
\text { Reussella, Pyrgo, etc. }\end{array}$ & $\begin{array}{c}\text { Konkian characteristic species; } \\
\text { predominance of euryhaline species } \\
\text { of genera: Elphidium, Nonion, Ammonia. } \\
\text { Presence of a small } \\
\text { number of normal-marine species } \\
\text { of genera: Bulimina, Cassidulina, } \\
\text { Quinqueloculina etc. is possible }\end{array}$ \\
\hline
\end{tabular}

Figure 1. Typical species of molluscs and foraminifera from the Konkian of the Eastern Parethetys (according to ZHIZHCHENKO, 1937a, b; MERKLIN, 1953; KRASHENINNIKOV, 1959; BARG, 1969; IVANOVA, 2012, etc.). 


\begin{tabular}{|c|c|c|c|c|c|c|c|c|c|c|c|c|c|c|}
\hline \multirow{2}{*}{\multicolumn{4}{|c|}{ GTS, 2004}} & \multirow{5}{*}{$\begin{array}{l}\text { Central } \\
\text { Paratethys } \\
\text { Stage }\end{array}$} & \multirow{5}{*}{$\begin{array}{l}\text { Eastern } \\
\text { Paratethys } \\
\text { Regional } \\
\text { stage }\end{array}$} & \multicolumn{9}{|c|}{ Representations about the stratigraphic value of "beds with fauna" } \\
\hline & & & & & & \multirow{2}{*}{\multicolumn{3}{|c|}{$\begin{array}{c}\text { "Beds with molluscs" are reflection regional } \\
\text { substages of the Konkian }\end{array}$}} & \multirow{2}{*}{\multicolumn{6}{|c|}{\begin{tabular}{c|c}
$?$ & "Beds with molluscs" are biostratigraphic units \\
$\longrightarrow$ & that are traced on different levels in coeval facies
\end{tabular}}} \\
\hline \multirow{3}{*}{$\frac{\varepsilon}{\Phi}$} & \multirow{3}{*}{$\begin{array}{l}\infty \\
\frac{0}{2} \\
\infty \\
\infty\end{array}$} & \multirow{3}{*}{ 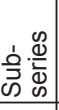 } & \multirow{3}{*}{$\begin{array}{l}\stackrel{0}{0} \\
\frac{\pi}{\omega} \\
\text { ஸ }\end{array}$} & & & & & & & & & & & \\
\hline & & & & & & \multirow{2}{*}{$\begin{array}{c}\text { Nothern Black } \\
\text { Sea Region }\end{array}$} & \multirow{2}{*}{$\begin{array}{l}\text { Crimea } \\
\text { Peninsula }\end{array}$} & \multirow{2}{*}{$\begin{array}{c}\text { Kerch } \\
\text { Peninsula }\end{array}$} & \multirow{2}{*}{\multicolumn{2}{|c|}{$\begin{array}{c}\text { Nothern Black } \\
\text { Sea Region }\end{array}$}} & \multirow{2}{*}{$\begin{array}{c}\text { Crimea } \\
\text { Peninsula }\end{array}$} & \multicolumn{3}{|c|}{ Kerch Peninsula } \\
\hline & & & & & & & & & & & & West & Centre & East \\
\hline \multirow{5}{*}{$\begin{array}{l}1 \\
ᄃ \\
0 \\
0 \\
0 \\
0 \\
z\end{array}$} & \multirow{5}{*}{$\begin{array}{l}0 \\
ᄃ \\
0 \\
0 \\
0 \\
- \\
\Sigma\end{array}$} & \multirow{5}{*}{$\begin{array}{l}\frac{0}{0} \\
0 \\
0 \\
\Sigma \\
\Sigma\end{array}$} & \multirow{5}{*}{ 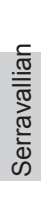 } & Sarmatian & Sarmatian & Sar & natian dep & & & & Sarmati & an dep & sits & \\
\hline & & & & \multirow{4}{*}{ 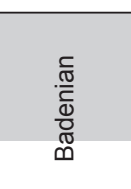 } & \multirow{3}{*}{ Konkian } & \multicolumn{3}{|c|}{ Veselyankian (Veselyanka Beds) } & \multirow{3}{*}{\multicolumn{3}{|c|}{ 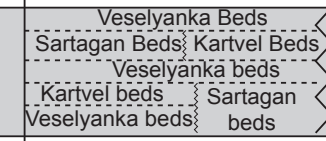 }} & \multirow{3}{*}{\multicolumn{3}{|c|}{$\begin{array}{l}\text { "beds with molluscs" are not } \\
\text { recognized in sections } \\
\mathrm{Z} \text { Kartvel beds }\end{array}$}} \\
\hline & & & & & & \multicolumn{3}{|c|}{ Sartaganian (Sartagan Beds) } & & & & & & \\
\hline & & & & & & \multicolumn{3}{|c|}{ Kartvelian (Kartvel Beds) } & & & & & & \\
\hline & & & & & Karaganian & \multicolumn{3}{|c|}{ Beds with Lutetia (Spaniodontella) gentilis } & \multicolumn{6}{|c|}{ Beds with Lutetia (Spaniodontella) gentilis } \\
\hline
\end{tabular}

- Research interval

Figure 2. The different understanding of stratigraphic value of the Kartvel Beds, Sartagan Beds and Veselyanka Beds in the Southern Ukraine deposits in stratigraphic schemes of the Konkian of the Eastern Paratethys.

searcher still decides to use individual names for these substages then it is proposed not to call them as Beds, but rather the Kartvelian substage, the Sartaganian substage and the Veselyankian substage (e.g. MAISSURADZE et al., 2014; PALCU et al., 2017). In addition, since the initial criteria for recognition of the Konkian substages were not universal, it is necessary to clarify the definitions for each of these substages by adding criteria to aid more accurate recognition of them in sections. At the same time, it is necessary to take into account the fact that the different facies of the Konkian deposits in the Eastern Paratethys generally contain stable species assemblages of fauna with certain palaeoecological characteristics that are separate biostratigraphic subdivisions "Beds with the fauna" (according to ZHAMOIDA, ed., 1977; TESLENKO, ed., 1997; GOZHYK, ed., 2012). In this case, it has been proposed to not call these subdivisions names such as the Kartvel Beds, the Sartagan Beds, the Veselianka Beds, but to name them after the characteristic fossils (e.g. limestones with Ervilia trigonula, Barnea pseudoustjurtensis) (VERNYHOROVA, 2014, 2015a,b, 2016).

\subsection{Criteria for determination of the initial (early) and final (late) development stages of the Konkian basin by molluscs and foraminifera}

Since the different Beds with fauna may occur at different stratigraphic levels of the Konkian of the Eastern Paratethys they are not unique for particular development phases of the Konkian ba$\sin$. Therefore, additional criteria for determination of the development stages of the Konkian basin are needed. Experience in the study of foraminifera and molluscs in the Konkian deposits from different areas of the Southern Ukraine, the Ciscaucasus and the Mangyshlak Peninsula (VERNIGOROVA et al., 2006,
2009; VERNIGOROVA, 2008, 2009, 2012; GOLOVINA et al., 2009; BRATISHKO et al., 2015) allows the definition of additional criteria for determination of the initial (early) and final (late) development stages of the Konkian basin (VERNYHOROVA, 2015a; POPOV et al., 2016).

An initial stage of the Konkian basin development may be recognized by a specific foraminiferal assemblage with a predominance of the genera Cassidulina and Discorbis (Cassidulina bulbiformis, C. bogdanowiczi KONENKOVA, Discorbis kartvelicus etc.) (Fig. 3). This regular trend can be observed in some relatively deep Konkian deposits (clays and marls) of the eastern part of the Crimean Peninsula, the Kerch Peninsula and the Ciscaucasus (KRASHENINNIKOV, 1959; BOGDANOWICZ, 1965; VERNYHOROVA, 2015a; POPOV et al., 2016; PALCU et al., 2017). This stage is clearly visible only in the most complete Konkian sections. Otherwise the stage is difficult to identify, because similar foraminiferal assemblages are present in different Konkian stratigraphic horizons, especially in the shallow-water deposits (VERNYHOROVA 2014, 2015a, b, 2016). Criteria for determining of the initial (early) development phase of the Konkian by molluscs are also not yet clearly defined. The early Konkian may contain Beds with Ervilia and Pholadidae. However, as has been indicated above, they are also present in other stratigraphic horizons.

The final development phase of the Konkian basin can be defined more precisely. These sediments comprise not only euryhaline species of molluscs and foraminifera which are typical for the Konkian basin but also a small amount of early Sarmatian species (e.g. molluscs - Obsoletiforma lithopodolica ruthenica (HILBER), Ervilia dissita dissita (EICHWALD) small-sized tests; foraminifera - Elphidium horridum, Porosononion mart-

\begin{tabular}{|c|c|c|c|}
\hline 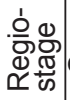 & $\begin{array}{c}\text { Phase of } \\
\text { development }\end{array}$ & Molluscs & Foraminifera \\
\hline \multirow{3}{*}{$\frac{\stackrel{c}{\frac{C}{c}}}{\stackrel{\frac{c}{c}}{O}}$} & late & $\begin{array}{c}\text { Predominance of Konkian euryhaline species and presence of } \\
\text { a small number of the early Sarmatian species } \\
\text { (e.g. E. dissita dissita, Obsoletiforma lithopodolica ruthenica; } \\
\text { their shells have small sizes) }\end{array}$ & $\begin{array}{c}\text { Predominance of Konkian euryhaline species and presence of } \\
\text { a small number of the early Sarmatian species } \\
\text { (e.g. E. horridum, Porosononion martkobi, } \\
\text { Nonion bogdanowichi ) }\end{array}$ \\
\hline & middle & \multicolumn{2}{|c|}{$\begin{array}{l}\text { A variety of molluscs and foraminiferal Konkian assemblages that have different paleoecological characteristics. } \\
\text { It is depend on environmental conditions in different areas of the Konkian basin especially in shallow-water deposits. }\end{array}$} \\
\hline & early & $?$ & $\begin{array}{c}\text { Konkian characteristic species; reduced species composition } \\
\text { of assemblages; normal-marine species; predominance of } \\
\text { the genera Cassidulina and Discorbis (e.g. C. bulbiformis, } \\
\text { C. bogdanowiczi, D. kartvelicus) }\end{array}$ \\
\hline
\end{tabular}

Figure 3. Characteristics of the Konkian development phases based on foraminifera and molluscs (VERNYHOROVA, 2015a). 
kobi (BOGDANOWICZ), Nonion bogdanowiczi VOLOSHINOVA). This regular trend can be observed in the Konkian sediments of the Northern Black Sea Region (including the Konkian stratotype), on the Kerch Peninsula, the Ciscaucasus and the Mangyshlak Peninsula (SOKOLOW, 1899; LIVEROVSKAYA, 1935; 1960; BOGDANOWICZ, 1965; VERNIGOROVA et al., 2009; VERNYHOROVA, 2014; BRATISHKO et al., 2015; PALCU et al., 2017).

\section{THE KONKIAN LITHOFACIES OF THE SOUTHERN UKRAINE}

The Konkian deposits of different lithofacies features are widespread in the Southern Ukraine (Figs. 4, 5). Shallow-water deposits (3-25 $\mathrm{m}$ thick) have accumulated in the Northern Black Sea Region and in most parts of the Crimean Peninsula (e.g. MOLYAVKO, 1960; BARG \& STEPANIAK, 2003). Different types of limestones (Hladkivka Formation, Tarkhankut Formation, Mekenziev Strata) prevail in the western part of the Northern Black Sea Region and in the western and southern parts of the Crimean Peninsula; sands and sandstones (Novokakhovka Formation) are more abundant in the south-east of the Northern Black Sea Region and in the northern and central parts of the Crimean Peninsula; laminated green-grey clays with varying sandy admixtures (Tymoshivka Formation) occur in the north-eastern part of the Northern Black Sea Region (VERNYHOROVA, 2015b, 2016). The Konkian deposits in these areas have sedimentation hiatuses and these strata are not stratigraphically complete (MOLYAVKO, 1960; DIDKOVSKIY \& KULICHENKO, 1975, VERNYHOROVA, 2015b, 2016).

More deep-water deposits (36-155 m thickness) are monotonous dark gray clays, partially laminated with rare sandy admixtures that have accumulated in the Kerch Peninsula and in the south-eastern parts of the Crimean Peninsula. They differ from other Konkian deposits of the Southern Ukraine by their litho- logical peculiarities and occurrence of more deep-water species of fauna (e.g. ANDRUSOV, 1917; OSIPOV, 1927; ARHANGUELSKY, 1930; ARKHANGUELSKY, ed., 1940; MOLYAVKO, 1960; BARG \& STEPANIAK, 2003; VERNYHOROVA, 2014). These Konkian deposits represent a complete stratigraphic sequence and all of them are combined in the Petrovske Formation (VERNIGOROVA et al., 2012; VERNYHOROVA, 2014).

\section{MATERIALS AND METHODS}

The Konkian deposits were studied in five wells from several regions of the Southern Ukraine (Figs. 4, 6). There are four wells from the Eastern Black Sea Region (upper part of the Tymoshivka Formation): Well 8z (altitude - $69.5 \mathrm{~m}$; thickness of the Konkian deposits - 4.2 m; 26 samples selected); Well 9 (altitude - $69.7 \mathrm{~m}$; thickness of the Konkian deposits - 1.7 m; 24 samples selected); Well 6 (altitude -30.5 m; thickness of the Konkian deposits - 5.0 m; 33 samples selected); Well 8m (altitude - 86,0 m; thickness of the Konkian deposits - 10.0 m; 47 samples selected) and one Well from the Kerch Peninsula (Petrovske Formation): Well 20 (altitude $-17.0 \mathrm{~m}$; thickness of the Konkian deposits - $51.0 \mathrm{~m}$; 82 samples selected). The stratigraphic sequence of these deposits was determined on the basis of foraminiferal and mollusc assemblages. Mollusc data from Well $8 \mathrm{z}$ were defined also by PRISYAZHNYUK et al., 2007 and were used in this research. During analysis, data on the Konkian foraminiferal and molluscs assemblages and lithological features of the Konkian deposits from other areas of the Southern Ukraine from published literature (e.g. DIDKOVSKIY, 1959; MOLYAVKO, 1960; BARG, 1993; BARG \& IVANOVA, 2000) and industrial-geological reports (1947-2015) were also utilised.

The selection and determination of all species of foraminifera was made from $300 \mathrm{~g}$ of sediment sample that was previously washed through a $76 \mu \mathrm{m}$ sieve (e.g. VERNIGOROVA et al., 2006; VERNIGOROVA, 2008). Descriptions and images of foramini-

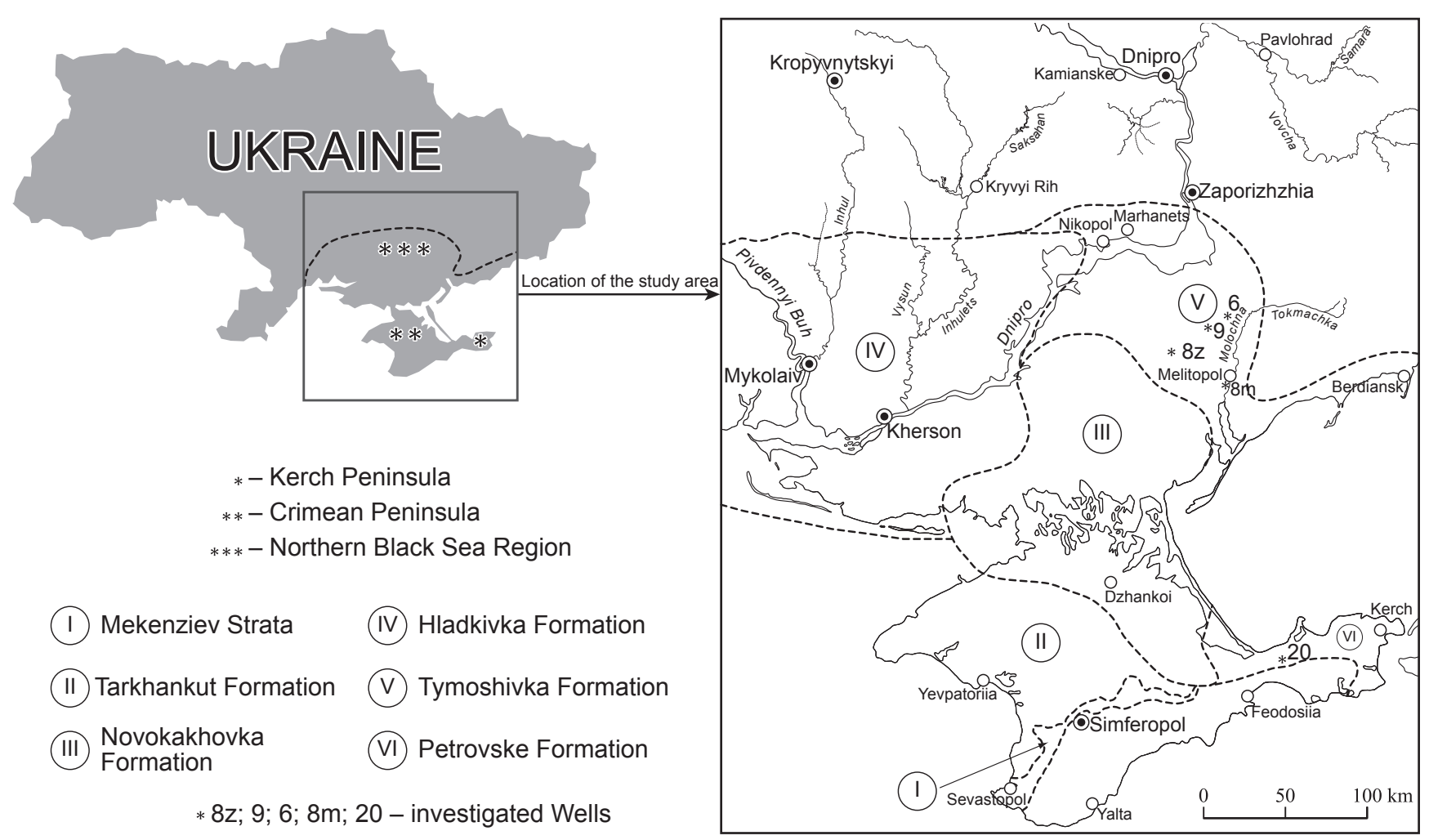

Figure 4. Location map of the studied wells in different facies of the Eastern Black Sea Region and the Kerch Peninsula. 

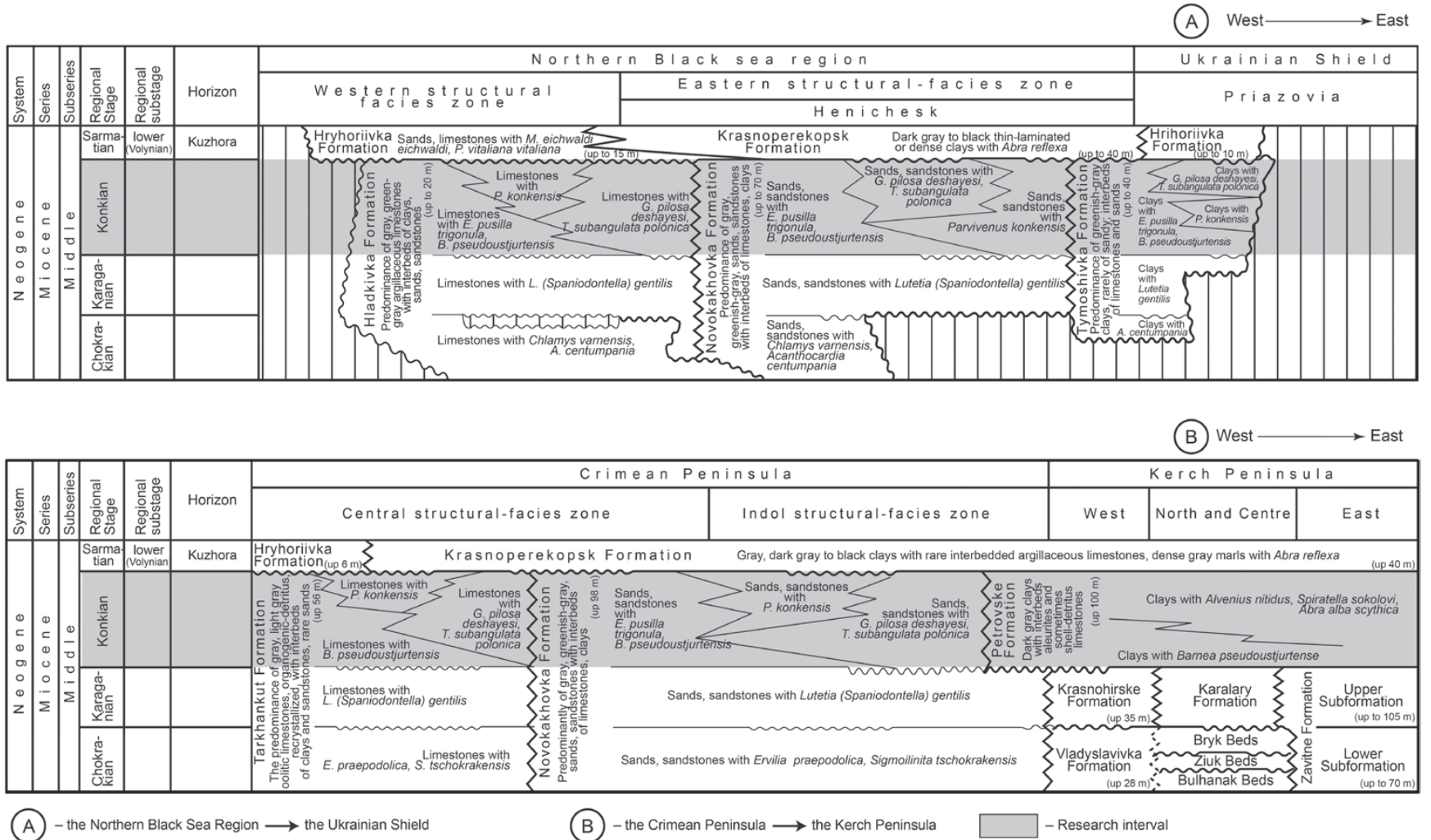

Figure 5. Stratigraphic scheme of the Konkian deposits of the Southern Ukraine (according to VERNYHOROVA, 2014, 2015a, b, 2016).

fera from the Neogene deposits of the Eastern Paratethys were used for their species determination (KRASHENINNIKOV, 1959; BOGDANOWICZ, 1952; DJANELIDZE, 1970; BUGROVA et al., 2005). Molluscs were extracted first, both from the vicinity of the wells and then during sample processing in the laboratory. Traditional conchological methods were used to identify molluscs (ILYINA, 1993; NEVESSKAYA et al., 1993).

The number of tests of each foraminifera species was counted in each sample for each well. Species were considered dominant when their percentage of tests was more than the percentage of tests of other species. The foraminiferal assemblages were compared based on the similarity of foraminifera species composition and the presence of the same dominant species. A definition of normal-marine, euryhaline, and mixed foraminiferal assemblages became possible after assessment of the palaeoecological characteristics of the foraminifera species composition of each assemblage. Comprehensive analysis of the data obtained from the Konkian stratigraphy of the Southern Ukraine is represented here. Descriptions and graphic presentation of qualitative and quantitative analyses of foraminiferal assemblages in the Konkian deposits from each of these wells is described in detail in: VERNIGOROVA, 2008, 2009, 2012; VERNIGOROVA et al., 2009.

Palaeoecological characteristics of foraminifera and molluscs (their classification as stenohaline, normal-marine and euryhaline species) is based on data from: ARKHANGUELSKY, ed., 1940; MERKLIN, 1953; DIDKOVSKIY \& KULICHENKO, eds., 1975; MURATOV \& NEVESSKAYA, eds., 1986; DIDKOVSKIY, 1959; KRASHENINNIKOV, 1959; BOGDANOWICZ, 1965; DJANELIDZE, 1970; ILYINA, 2000; MAISSURADZE et al., 2014; ZHGENTI \& MAISSURADZE, 2016, etc.

Analysis of changes of foraminifera and molluscs species composition gave possibility to understand the peculiarities of the development of different regions of southern Ukraine in
Konkian time. Palaeoecological and stratigraphic reconstruction of the middle Miocene deposits of the Eastern Black Sea Region was created using palaeoecological, bio- and lithostratigraphic data that were obtained both from published literature and the author's research (e.g. ARKHANGUELSKY, ed., 1940; DIDKOVSKIY, 1959; MOLYAVKO, 1960; BARG, 1969, 2008; PRISYAZHNYUK et al., 2007; VERNIGOROVA, 2008, 2009, 2012; VERNIGOROVA et al., 2009; VERNYHOROVA, 2014, 2015b, 2016).

\section{RESULTS AND DISCUSSION}

\subsection{Peculiarities of foraminifera and molluscs assemblages in the Konkian deposits of the studied area}

Five stenohaline normal-marine (NM1-NM5), two euryhaline (EH1, EH2) and one mixed (MX) foraminiferal assemblages were identified within the cores of the investigated wells at different levels (Figs. 7, 8). They are characterized by the predominance of either normal-marine or euryhaline foraminiferal taxa (e.g. KRASHENINNIKOV, 1959; BOGDANOWICZ, 1965; DJANELIDZE, 1970; KRASHENINNIKOV et al., 2003) or an equal number of marine and euryhaline foraminiferal taxa (DIDKOVSKIY, 1959; VERNIGOROVA, 2012) accordingly.

Assemblage NM1 is characterized by dominant species: Quinqueloculina minakovae ukrainica, Q. pseudoangustissima KRASHENINNIKOV, $Q$. ex gr. consobrina ORBIGNY, Varidentella reussi sartaganica, Triloculina inflata ORBIGNY, T. ebersini DIDKOVSKIY, Globulina gibba ORBIGNY and subdominant species: Triloculina inornata ORBIGNY, Spiroloculina konkensis BOGDANOWICZ, Sigmoilina sp., Florilus boueanus ORBIGNY, Nonion sp.1, Elphidium joukovi SEROVA, Ammonia ex gr. beccarii (LINNÉ). It was determined in three wells in the eastern part 


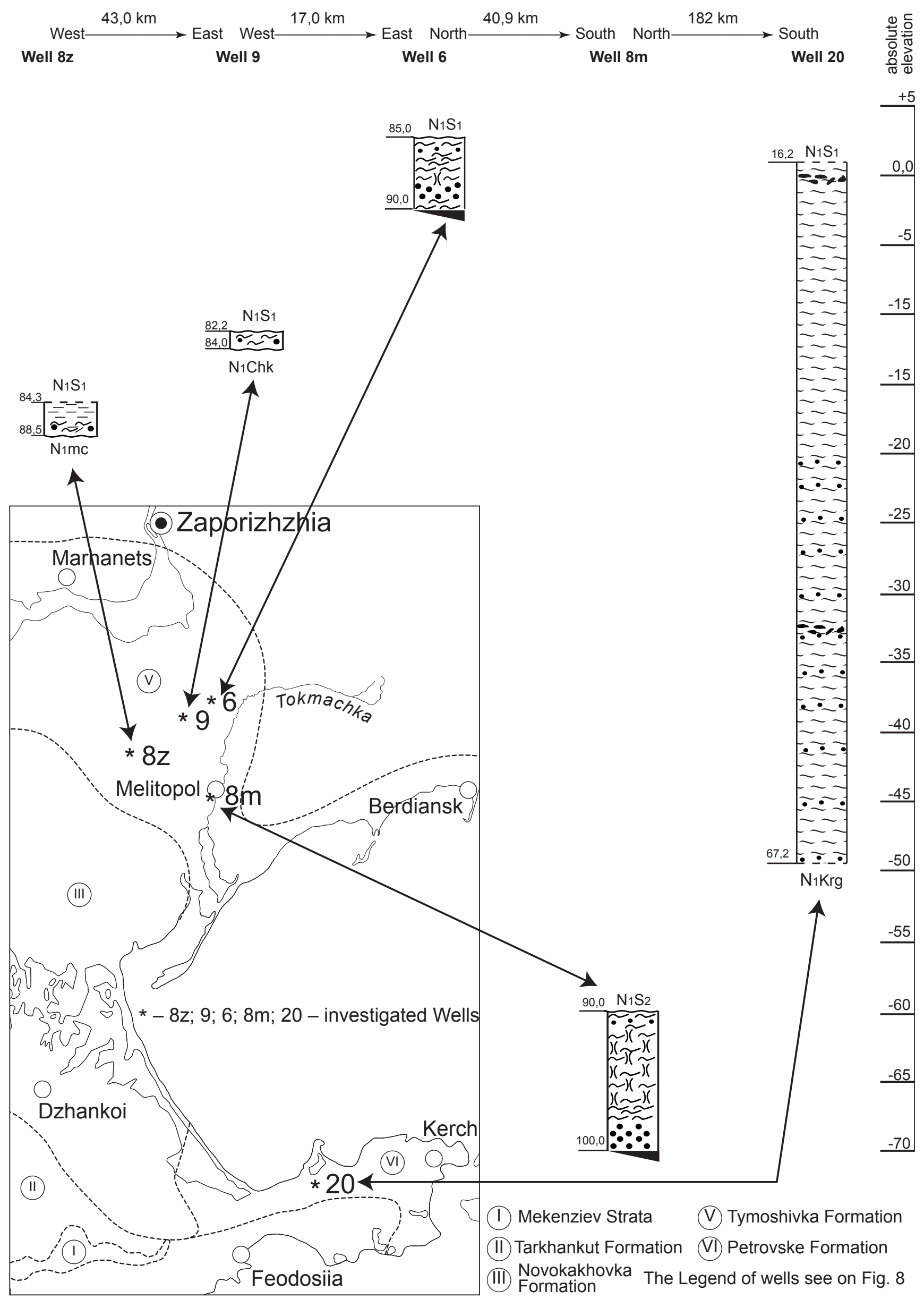

Figure 6. Location of the wells and schematic section of the Konkian deposits from Wells 8z, 9, 8m, and 20. 
of the Northen Black Sea Region (Figs. 6, 8). The Well 8z (88.3$87.8 \mathrm{~m}$ ) is characterized by the interbedding of light yellow-grey and green-grey loose or dense argillaceous limestones. Well 9 $(83.0-82.65 \mathrm{~m})$ is characterized by light-gray with a greenish tinge, dense, laminated, carbonate clays with sandy grains on bedding planes. Well $6(87.15-87.0 \mathrm{~m})$ is characterized by black with a greenish tinge argillite clays. Different molluscs were found together with this foraminiferal assemblage (Figs. 7, 8). Namely, rare shells of Mytilaster volhynicus (EICHWALD), Ervilia pusilla trigonula SOKOLOV, Gibbula aff. bajarunasi (KOLESNIKOV), Nassarius aff. karaganicus (ZHIZHCHENKO) were observed in
Well 8z; similar molluscs species composition and also many shells of Ervilia pusilla trigonula were found in Well 9; Nassarius aff. karaganicus, Ervilia pusilla trigonula and rare Hydrobia sp., Alvenius nitidus (REUSS) were found in Well 6. These are normal-marine mollusc assemblages (Fig. 7) or Sartagan Beds (in the sense of MERKLIN, 1953; MURATOV \& NEVESSKAYA, eds., 1986). Also the numerous shells of ostracods, remnants of bryozoans and echinoid radiole were found together with this foraminiferal assemblage (Figs. 7, 8).

Assemblage NM2 is characterized by a small number of specimens of: Quinqueloculina gracilis KARRER, Q. aff. guri-

\begin{tabular}{|c|c|c|c|c|c|c|c|c|}
\hline 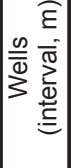 & $\begin{array}{l}8 z(88,5-87,8 m) \\
9(83,0-82,65 \mathrm{~m}) \\
6(87,15-87,0 \mathrm{~m})\end{array}$ & $8 z(87,8-87,0 \mathrm{~m})$ & $8 z(86,9-86,3 \mathrm{~m})$ & $\begin{array}{r}6(87,3-87,2 \mathrm{~m} \\
85,8-85,0 \mathrm{~m})\end{array}$ & $20(67,2-18,1 \mathrm{~m})$ & $\begin{array}{c}9(83,7-83,0 \mathrm{~m}) \\
6(87,0-86,6 \mathrm{~m}) \\
8 \mathrm{~m}(96,75-96,7 \mathrm{~m} \\
\quad 93,5-93,45 \mathrm{~m})\end{array}$ & $\begin{array}{c}9(84,0-83,7 \mathrm{~m}) \\
6(88,5-87,5 \mathrm{~m} \\
87,35-87,3 \mathrm{~m} \\
86,6-85,8 \mathrm{~m}) \\
8 \mathrm{~m}(100,0-96,5 \mathrm{~m})\end{array}$ & $\begin{array}{l}8 z(86,3-84,3 \mathrm{~m}) \\
20(18,1-16,2 \mathrm{~m})\end{array}$ \\
\hline & \multicolumn{4}{|c|}{ Eastern part of the Nothern Black Sea Region } & Kerch Peninsula & \multicolumn{3}{|c|}{$\begin{array}{c}\text { Eastern part of the Nothern Black Sea Region } \\
\mid \text { Kerch Peninsula } \\
\end{array}$} \\
\hline \multirow[b]{3}{*}{ 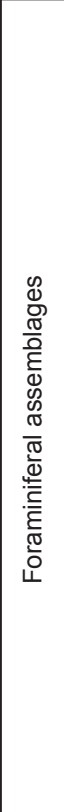 } & \multicolumn{5}{|c|}{ Beds with predominance of normal-marine species } & \multicolumn{3}{|c|}{$\begin{array}{c}\text { Beds with predominance } \\
\text { of euryhaline species }\end{array}$} \\
\hline & $\begin{array}{l}\text { assemblage } \\
\text { NM1 }\end{array}$ & $\begin{array}{l}\text { assemblage } \\
\text { NM2 }\end{array}$ & $\begin{array}{l}\text { assemblage } \\
\text { NM3 }\end{array}$ & $\begin{array}{l}\text { assemblage } \\
\text { NM4 }\end{array}$ & $\begin{array}{l}\text { assemblage } \\
\text { NM5 }\end{array}$ & $\begin{array}{l}\text { assemblage } \\
\mathrm{MX}\end{array}$ & $\begin{array}{c}\text { assemblage } \\
\mathrm{EH} 1\end{array}$ & $\begin{array}{c}\text { assemblage } \\
\mathrm{EH} 2\end{array}$ \\
\hline & $\begin{array}{l}\text { Dominant } \\
\text { species: } \\
\text { Q. minakovae } \\
\text { ukrainica, } \\
\text { Q. pseudo- } \\
\text { angustissima, } \\
\text { Q. ex gr. } \\
\text { consobrina, } \\
\text { V. reussi } \\
\text { sartaganica, } \\
\text { Triloculina inflata, } \\
\text { T. ebersini, } \\
\text { Globulina gibba } \\
\text { Subdominant } \\
\text { species: } \\
\text { T. inornata, } \\
\text { S. konkensis, } \\
\text { Sigmoilina sp., } \\
\text { F. boueanus, } \\
\text { Nonion sp.1, } \\
\text { E. joukovi, } \\
\text { A. ex gr. beccarii }\end{array}$ & $\begin{array}{l}\text { Small sizes, poor } \\
\text { preservation, } \\
\text { small number of } \\
\text { shells: } \\
\text { Q. gracilis, } \\
\text { Q. minakovae } \\
\text { ukrainica, } \\
\text { Q. ex gr. } \\
\text { consobrina, } \\
\text { Q. aff. guriana, } \\
\text { Q. angustissima, } \\
\text { V. reussi } \\
\text { sartaganica, } \\
\text { T. inflata, } \\
\text { G.gibba, } \\
\text { D. supinus, } \\
\text { D. squamulus, } \\
\text { Spirolina sp., } \\
\text { F. boueanus, } \\
\text { Nonion sp., } \\
\text { A. ex gr. beccarii }\end{array}$ & $\begin{array}{l}\text { Equal quantities } \\
\text { of shells: } \\
\text { H. aff. podolica, } \\
\text { Hauerina sp. } 1 \text {, } \\
\text { Hauerina sp. } 2 \text {, } \\
\text { Discorbis sp. } 1 \text {, } \\
\text { Discorbis? sp. } 2\end{array}$ & $\begin{array}{l}\text { Subdominant } \\
\text { species: } \\
\text { V. reussi } \\
\text { sartaganica, } \\
\text { Nonionella } \\
\text { ventragranossa, } \\
\text { N. tauricus, } \\
\text { El. antonina, } \\
\text { Elphidium sp. }\end{array}$ & $\begin{array}{l}\text { Different } \\
\text { quantitaties } \\
\text { of shells } \\
\text { throughout } \\
\text { the section: } \\
\text { Q. gracilis, } \\
\text { Q. guriana, } \\
\text { B. floridana, } \\
\text { B. dilatata, } \\
\text { N. elongata, } \\
\text { U. gracilissima, } \\
\text { Fursenkoina } \\
\text { schreibersiana, } \\
\text { G. aff. austriaca, } \\
\text { D. kartvelicus, } \\
\text { Cassidulina sp. }\end{array}$ & $\begin{array}{l}\text { Equal quantities } \\
\text { of shells: } \\
\text { Large shells } \\
\text { of euryhaline } \\
\text { species: } \\
\text { Porosononion } \\
\text { subgranosus, } \\
\text { E. aculeatum, } \\
\text { A. ex gr. beccarii } \\
\text { and small shells } \\
\text { of stenohaline } \\
\text { species: } \\
\text { B. dilatata, } \\
\text { N. elongata, } \\
\text { U. gracilissima, } \\
\text { Fursenkoina } \\
\text { schreibersiana, } \\
\text { G. aff. austriaca, } \\
\text { R. spinulosa, } \\
\text { Discorbis sp.1, } \\
\text { Cassidulina sp. }\end{array}$ & $\begin{array}{l}\text { Subdominant } \\
\text { species: } \\
\text { Fl. boueanus, } \\
\text { Q. aff. guriana, } \\
\text { V.reussi } \\
\text { sartaganica, } \\
\text { Discorbis sp., } \\
\text { N. tauricus, } \\
\text { El.joukovi }\end{array}$ & $\begin{array}{l}\text { In upper parts } \\
\text { of some } \\
\text { Konkian sections } \\
\text { The same } \\
\text { species } \\
\text { compositions } \\
\text { as EH1 } \\
\text { assemblage } \\
\text { and also } \\
\text { admixture of } \\
\text { shells of } \\
\text { the Early } \\
\text { Sarmatian } \\
\text { species: } \\
\text { E. reginum, } \\
\text { E. horridum, } \\
\text { Q. consobrina } \\
\text { sarmatica, } \\
\text { Articulina sp., } \\
\text { Entosolenia sp. }\end{array}$ \\
\hline \multirow{4}{*}{ 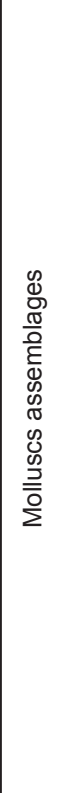 } & \multirow{4}{*}{$\begin{array}{l}\text { Normal-marine: } \\
\text { Well } 8 z \\
\text { rare shells of } \\
\text { M. volhynicus, } \\
\text { E. pusilla trigonula, } \\
\text { G. aff. bajarunasi, } \\
\text { N.aff. karaganicus; } \\
\text { Bryozoans, } \\
\text { echinoid radiole } \\
\\
\text { Well } 9 \\
\text { similar on well } \\
8 z \text { but has also } \\
\text { many shells of } \\
\text { Ervilia pusilla } \\
\text { trigonula; } \\
\text { Bryozoans, } \\
\text { echinoid radiole } \\
\text { Well } 6 \\
N \text {. aff. karaganicus } \\
\text { E.pusilla trigonula, } \\
\text { rare:Hydrobia sp., } \\
\text { Al.nitidus, } \\
\text { Bryozoans, } \\
\text { echinoid radiole }\end{array}$} & \multirow[t]{4}{*}{$\begin{array}{l}\text { Beds with } \\
\text { Pholadidae: } \\
\text { Well } 8 \\
\text { many shells of } \\
\text { Barnea } \\
\text { pseudoustjurtensis } \\
\text { single shells of } \\
\text { E. pusilla trigonula, } \\
\text { Hydrobia sp. }\end{array}$} & \multirow[t]{4}{*}{$\begin{array}{l}\text { Beds with } \\
\text { Ervilia and } \\
\text { Pholadidae: } \\
\text { Well } \mathbf{8 z} \\
\text { many shells of } \\
\text { E. pusilla trigonula, } \\
\text { Barnea } \\
\text { pseudoustjurtensis, } \\
\text { Hydrobia sp. } \\
\text { and shells detritus }\end{array}$} & \multirow[t]{4}{*}{$\begin{array}{l}\text { Normal-marine: } \\
\text { Well } 6 \\
\text { Anadara turonica, } \\
\text { V. (Polititapes) } \\
\text { vitaliana, } \\
\text { P. praeplicata, } \\
\text { E. pusilla trigonula, } \\
\text { Obsoletiforma } \\
\text { lithopodolica } \\
\text { ruthenica, } \\
\text { Retusa sp., } \\
\text { N.millepunctata }\end{array}$} & \multirow[t]{2}{*}{$\begin{array}{l}\text { Rare shells } \\
\text { throughout } \\
\text { the section } \\
\text { Well 20: } \\
\mathbf{4 5 , 7 - 1 8 , 1 ~ m} \\
\text { S. konkensis, } \\
\text { Alvenius nitidus, } \\
\text { Mactra sp., } \\
\text { and shells } \\
\text { detritus }\end{array}$} & $\begin{array}{l}\text { Euryhaline } \\
\text { and Spirialis: } \\
\text { Well } 8 \mathrm{~m} \text { : } \\
96,7 ; 93,5 \mathrm{~m} \\
\text { Alvenius nitidus, } \\
\text { E. pusilla trigonula, } \\
\text { Cardium sp., } \\
\text { Venus sp. } \\
\text { and plus } \\
\text { Spiratella sp. }\end{array}$ & $\begin{array}{l}\text { Euryhaline: } \\
\text { Well 6: } \\
88,5-87,5 \mathrm{~m} \\
87,35-87,3 \mathrm{~m} \text {; } \\
8 \mathrm{~m}: \\
96,2-93,8 \mathrm{~m} \\
93,0-91,6 \mathrm{~m} \\
91,1-90,0 \mathrm{~m} \\
\text { A. nitidus, } \\
\text { E. pusilla, } \\
\text { Venus sp. }\end{array}$ & $\begin{array}{l}\text { Euryhaline: } \\
\text { Well } \mathbf{8 z} \\
\text { rare shells of } \\
\text { Hydrobia sp., } \\
\text { E. pusilla trigonula, } \\
\text { Alvenius nitidus } \\
\text { and some } \\
\text { terrestrial } \\
\text { species }\end{array}$ \\
\hline & & & & & & \multirow{2}{*}{$\begin{array}{l}\text { Beds with } \\
\text { Pholadidae } \\
\text { Well 9: } \\
83,50-83,32 \text { m } \\
\text { many shells of } \\
\text { Barnea } \\
\text { pseudoustjurtensis } \\
\text { and shell detritus }\end{array}$} & $\begin{array}{l}\text { Beds with } \\
\text { Pholadidae } \\
\text { Well 8m: } \\
\text { 100,0-97,8 m } \\
96,4-96,2 \mathrm{~m}\end{array}$ & \multirow[t]{3}{*}{$\begin{array}{l}\text { Shells detritus } \\
\text { and rare } \\
\text { small shells } \\
\text { of } \\
\text { Cardium sp. } \\
\text { Well } 20 \text { : } \\
18,1-16,2 \mathrm{~m}\end{array}$} \\
\hline & & & & & \multirow{2}{*}{$\begin{array}{l}\text { Beds with } \\
\text { Pholadidae } \\
\text { Well 20: } \\
\mathbf{5 4 , 7 - 4 5 , 7 ~ m} \\
\text { many shells of } \\
\text { Barnea } \\
\text { pseudoustjurtensis } \\
\text { and shells detritus }\end{array}$} & & \multirow{2}{*}{$\begin{array}{l}\text { Beds with } \\
\text { Ervilia } \\
\text { Well 9: } \\
84,0-83,93 \mathrm{~m} ; \\
\text { Well 6: } \\
86,6-85,8 \mathrm{~m} \\
\text { many shells of } \\
\text { E. pusilla trigonula }\end{array}$} & \\
\hline & & & & & & $\begin{array}{r}\text { Shells detritus } \\
\text { Well 9: } 83,7-83,5 \mathrm{~m} \\
83,3-85,8 \mathrm{~m} \\
\text { Well 6: } 88,0-87,5 \mathrm{~m} \\
87,0-86,6 \mathrm{~m}\end{array}$ & & \\
\hline
\end{tabular}

Figure 7. General characteristics of foraminiferal and mollusc assemblages in the studied Wells (for detailed analyses of these assemblages in the Konkian deposits of each of these wells see also: PRISYAZHNYUK et al., 2007; VERNIGOROVA, 2008, 2009, 2012; VERNIGOROVA et al., 2009). 

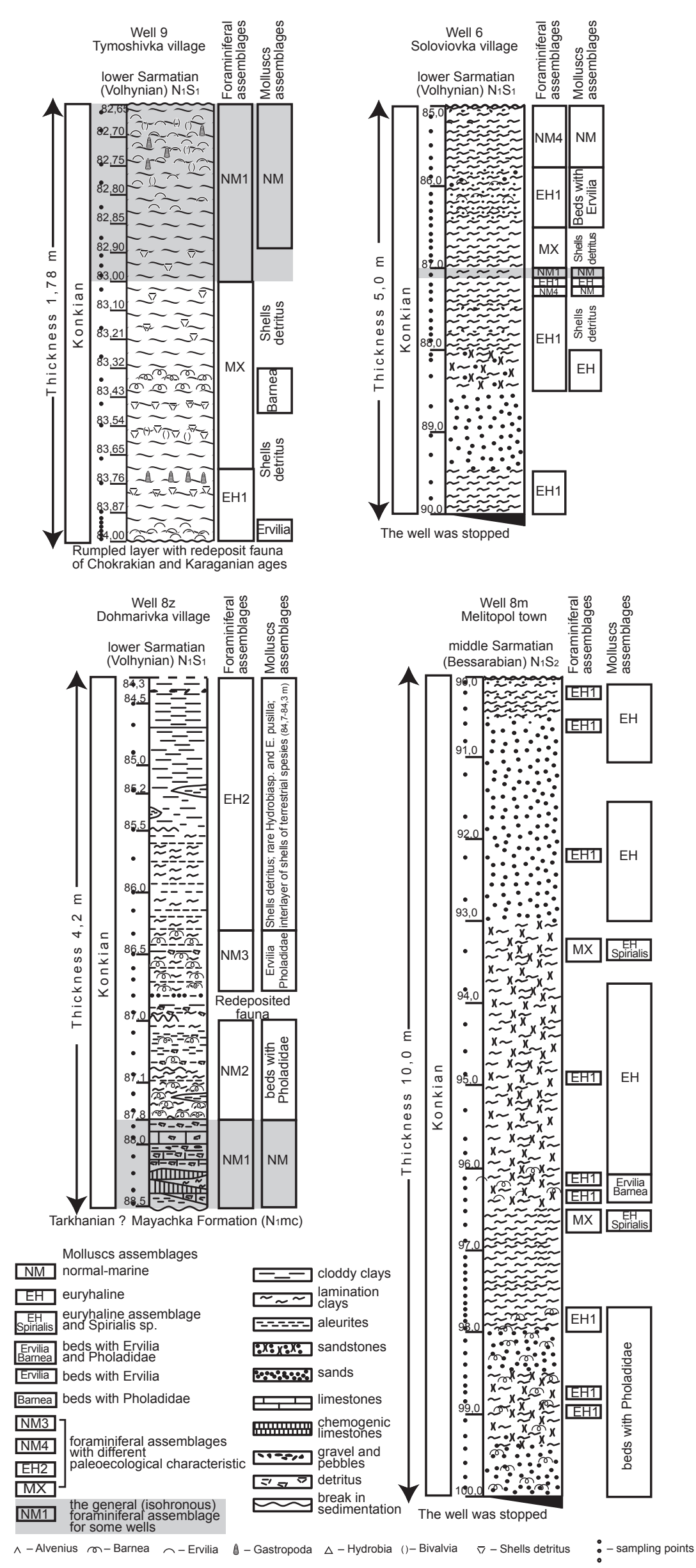

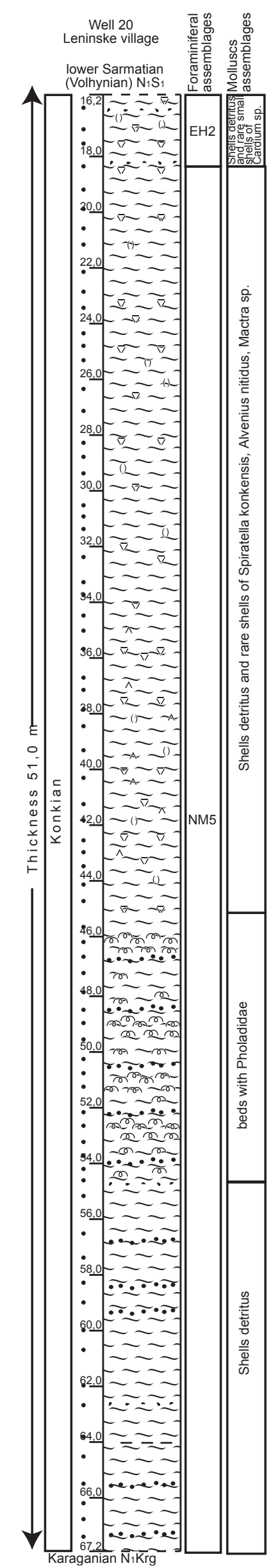

Figure 8. Distribution of foraminiferal and molluscs assemblages in the Konkian deposits of the studied wells. 
ana DJANELIDZE, $Q$. minakovae ukrainica, $Q$. ex gr. consobrina, Q. pseudoangustissima, Varidentella reussi sartaganica, Triloculina inflata, Globulina gibba, Discorbis supinus, D. squamulus (REUSS), Spirolina sp., Florilus boueanus, Nonion sp., Ammonia ex gr. beccarii. It was determined in Well 8z (87.8-87.0 $\mathrm{m}$ ) in the eastern part of the Northen Black Sea Region (Figs. 6, 8). This interval is characterized by dark grey viscous clays with aleurite powders grains on bedding planes. The numerous mollusc shells of Barnea pseudoustjurtensis and fragments of Ervilia pusilla trigonula and Hydrobia sp. were found together with this foraminiferal assemblage (Figs. 7, 8). These are Beds with Pholadidae (Fig. 7) or Kartvel Beds (in the sense of Merklin, 1953; MURATOV \& NEVESSKAYA, eds., 1986).

Assemblage NM3 is characterized by equal quantities of poorly preserved tests: Hauerina podolica SEROVA, Hauerina sp. 1, Hauerina sp. 2, Discorbis sp. 1, Discorbis? sp. 2. It was determined in Well 8z (86.9-86.3 m) in the eastern part of the Northern Black Sea Region (Figs. 6, 8). These deposits are characterized by interbeddings of greenish-light-grey aleurites and darker clays. The numerous mollusc shells of Barnea pseudoustjurtensis, Ervilia pusilla trigonula and single shells of Hydrobia sp. were found together with this foraminiferal assemblage (Figs. 7, 8). These are Beds with Ervilia and Pholadidae (Fig. 7) or the Kartvel Beds (in the sense of BARG, 1969).

Assemblage NM4 is characterized by the dominant species: Reussela spinulosa, Spirolina austriaca ORBIGNY, Dendritina cf. haueri ORBIGNY, Borelis melo and subdominant species: Varidentella reussi sartaganica, Nonionella ventragranossa KRASHENINNIKOV, Nonion tauricus, Elphidium antonina KRASHENINNIKOV, Elphidium sp. It was determined in two levels of Well 6 (87.3-87.2 m; 85,8-85.0 m) in the eastern part of the Northern Black Sea Region (Figs. 6, 8). These deposits are characterized by greenish-dark-grey dense clays. The numerous mollusc shells have been found together with this foraminiferal assemblage (Figs. 7, 8). There are Anadara turonica (DUJARDIN), Venerupis (Polititapes) vitaliana (ORBIGNY), Plicatiforma praeplicata (HILBER), Ervilia pusilla trigonula, Obsoletiforma lithopodolica ruthenica, Retusa sp., Natica millepunctata LAMARK. These are normal-marine molluscs assemblages (Fig. 7) or Sartagan Beds (in the sense of Merklin, 1953; MURATOV \& NEVESSKAYA, eds., 1986).

Assemblage NM5 is characterized by different abundances of foraminiferal tests in each sample without an obvious predomination of a particular species: Quinqueloculina gracilis, Q. guriana, Bolivina floridana CUSHMAN, B. dilatata REUSS, Neobulimina elongata (ORBIGNY), Uvigerina gracilissima POBEDINA, Fursenkoina schreibersiana (CZJZEK), Guttulina aff. austriaca ORBIGNY, Discorbis kartvelicus, Cassidulina sp. It was determined in Well 20 (67.2-18.1 m) in the western part of the Kerch Peninsula (Fig. 6, 8). These deposits are characterized by grey to light grey dense, thinly-laminated clays sometimes sandy, with aleurite powders on interbeddings. Rare mollusc shells of Limacina konkensis (ZHIZHCHENKO), Alvenius nitidus, Mactra sp., and shell detritus were found together with this foraminiferal assemblage (Figs. 7, 8). In addition, many shells of Barnea pseudoustjurtensis were found only in one part of the deposits (Well 20: 54.7$45.7 \mathrm{~m}$ ) and these are Beds with Pholadidae (Fig. 7) or the Kartvel Beds (in the sense of MERKLIN, 1953; MURATOV \& NEVESSKAYA, eds., 1986).

Assemblage EH1 is characterized by dominant species: Porosononion subgranosus (EGGER), Elphidium macellum (FICHTEL \& MOLL), Ammonia ex gr. beccarii and subdominant species: Florilus boueanus, Q. aff. guriana, Varidentella reussi sartaganica, Discorbis sp., Nonion tauricus, Elphidium joukovi. It was determined in two Wells: 9 (84.0-83.7 m); 8m (in several samples in interval 100.0-96.5 m) and on three levels of Well 6 (88.5-87.5 m; 87.35-87.3 m; 86.6-85.8 $\mathrm{m}$ ) in the eastern part of the Northern Black Sea Region (Fig. 6, 8). These deposits are characterized by greenish-dark-grey clays (Well 9); light-grey laminated clays with aleurite powders on interbeddings (Well 8m: 96.5-98.8 $\mathrm{m})$, light-grey with a greenish tinge fine-grained, sometimes clayey quartz sands (Well 8m: 98.5-100.0 m ); interbeds of greenish-dark-grey dense clays and light-grey sandstones, with interbeds of light-grey quartz sands (Well 6: 88.5-87.3 m, 87.35-87.3 $\mathrm{m}, 86.6-85,8 \mathrm{~m})$. Different molluscs were found together with this assemblage (Fig. 7, 8). Rare mollusc shells of Alvenius nitidus, Ervilia pussila trigonula, Venus sp. were found together with this foraminiferal assemblage in Well $6(88.5-87.3 \mathrm{~m}, 87.35-87.3 \mathrm{~m})$ and in Well 8 (96.2-93.8 $\mathrm{m}$; 93.0-91.6 m; 91.1-90.0 m). These are euryhaline mollusc assemblages (Fig. 7) or Veselyanka Beds (in the sense of Merklin, 1953; MURATOV \& NEVESSKAYA, eds., 1986). Also, many shells of Barnea pseudoustjurtensis were found only in Well 8 (100.0-97.8 m; 96.4-96.2 m). These are Beds with Pholadidae (Fig. 7) or Kartvel Beds (in the sense of MERKLIN, 1953; MURATOV \& NEVESSKAYA, eds., 1986). And also many shells of Ervilia pussila trigonula and mollusc detritus were found in Wells 9 and 6 (86.6-85.8 m). These are Beds with Ervilia and Pholadidae (Fig. 7) or Kartvel Beds (in the sense of BARG, 1969).

Assemblage EH2 is characterized by the same species composition as assemblage EH1 but also comprises some tests of the Early Sarmatian species: Elphidium reginum (ORBIGNY), E. horridum, Quinqueloculina consobrina sarmatica GERKE, Articulina sp., Entosolenia sp. This assemblage was determined in the upper part of the Konkian deposits before the Konkian/Sarmatian boundary in Well 8z (86.3-84.3 m) in the eastern part of the Northern Black Sea Region and Well 20 (18.1-16.2 m) in the western part of the Kerch Peninsula (Fig. 6, 8). It characterizes the final development stage of the Konkian basin (VERNYHOROVA, 2015a, b, 2016). These deposits are characterized by interbeds of greenish-light-grey aleurites and clays, bluish-lightgrey non-laminated carbonate clays at the top of the interval (Well 8z); grey aleuritic, massive, thick-laminated clays with aleurite powders on interbeddings (Well 20). Rare mollusc shells of Hydrobia sp., Ervilia pusilla trigonula, Avenius nitidus and some terrestrial species in Well $8 \mathrm{z}$ and shells detritus with scarce small shells of Cardium sp. (Well 20) were found together with this assemblage (Figs. 7, 8). The Konkian age of deposits with this assemblage was confirmed in Well $8 \mathrm{z}$ by molluscs and ostracods (PRISYAZHNYUK et al., 2007).

Assemblage MX is characterized by equal abundance of large tests of euryhaline species: Porosononion subgranosus, Elphidium aculeatum, Ammonia ex gr. beccarii and small tests of stenohaline species: Bolivina dilatata, Neobulimina elongata, Uvigerina gracilissima, Fursenkoina schreibersiana, Guttulina aff. austriaca, Reussela spinulosa, Discorbis sp.1, Cassidulina sp. This assemblage was determined in different levels of three Wells: 9 (83.7-83.0 m); 6 (87.0-86.6 m); 8m (96,75-96,7 m; 93,5$93,45 \mathrm{~m})$ in the eastern part of the Northern Black Sea Region. These deposits are characterized by light-grey carbonate dense clays (Well 9); black with a greenish tinge dense clays (Well 6); light-grey laminated clays with aleurite grains on interbeddings (Well 8m: 96.75-96.7 m) light-grey fine-grained, carbonate sandstones (Well 8m: 93.5-93.45 m). Different molluscs were found together with this assemblage (Fig. 7, 8). Namely, rare mollusc shells of Alvenius nitidus, Ervilia pusilla trigonula, Cardium sp., Venus sp. and Limacina sp. (mixed mollusc assemblage) were 


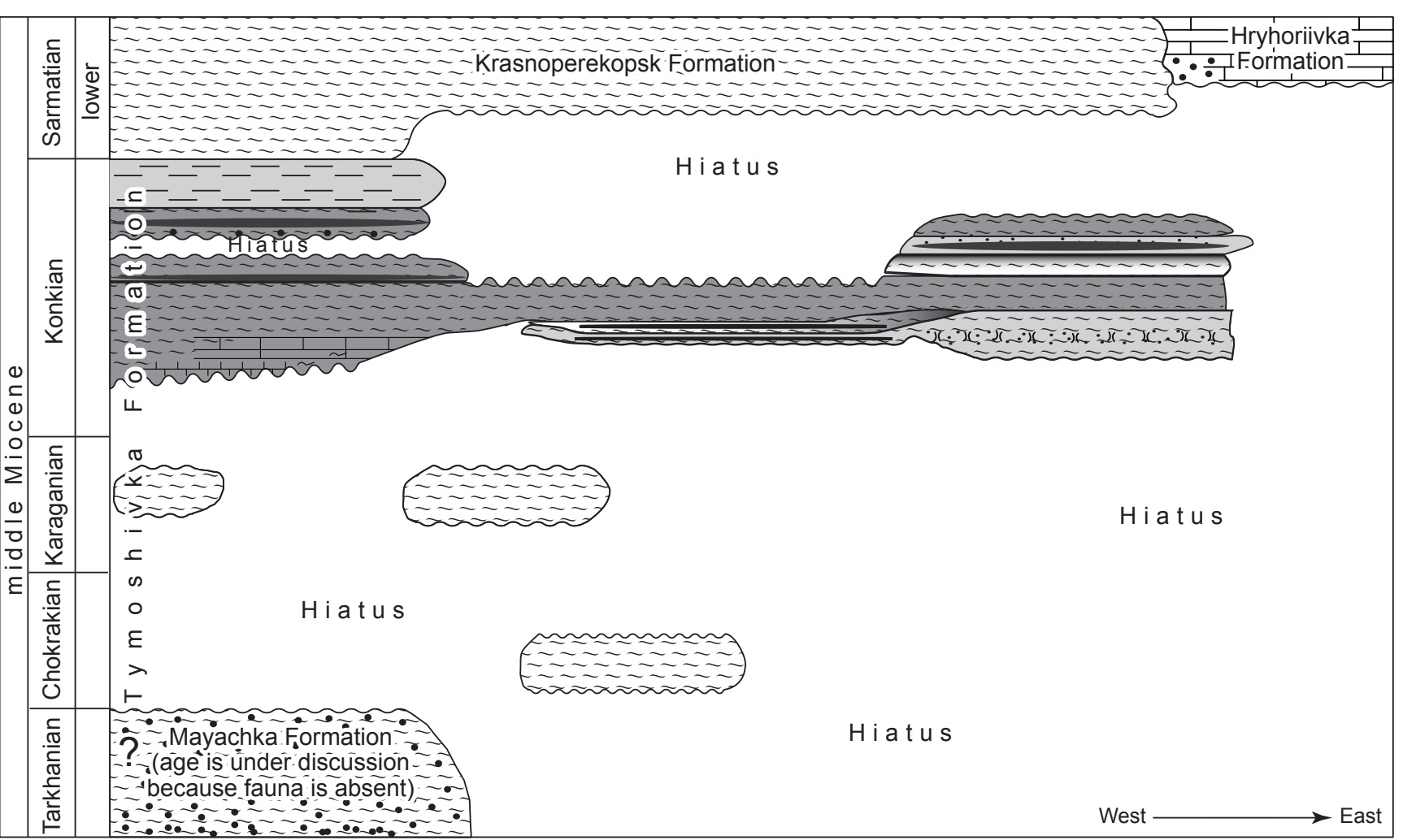

The legend of the rocks is shown at the Fig. 8

Faunal assemblages: $\square$ normal-marine euryhaline

Figure 9. Palaeoecological and stratigraphic reconstruction of the middle Miocene deposits of the Eastern Black Sea Region.

found in Well 8m; the numerous molluscs shells of Barnea pseudoustjurtensis (Beds with Pholadidae - in the sense of MERKLIN, 1953; MURATOV \& NEVESSKAYA, eds., 1986) were found in a thin layer in Well $9(83.5-83.32 \mathrm{~m})$; shells detritus were found in Well 6 and Well 9 (83.7-83.5; 83.32-83.0 m).

\subsection{Biostratigraphic reconstruction of the Konkian deposits of the Southern Ukraine based on foraminifera}

Shallow-water Konkian deposits of the Eastern Black Sea Region (Tymoshivka Formation) contain several foraminiferal assemblages with different taxonomic composition and palaeoecological characteristics. They occur together with different mollusc assemblages (Figs. 7, 8). Normal-marine foraminiferal assemblages (NM1-NM4) are accompanied by adequate mollusc assemblages (single levels of Wells 8z; 9; 6) and also by Beds with Pholadidae and by Beds with Ervilia and Pholadidae (two levels of Well 8z). The euryhaline foraminiferal assemblages (EH1; EH2) are accompanied by euryhaline mollusc assemblages (different levels of Wells $6 ; 8 \mathrm{~m}$ ) and also by Beds with Pholadidae and by Beds with Ervilia (different levels of Wells 9; 6; 8m). A mixed foraminiferal assemblage (MX) is accompanied by mixed mollusc assemblages (two levels of Well $8 \mathrm{~m}$ ) and also by Beds with Pholadidae (single level of Well 9). Also, some levels with different foraminiferal assemblages are composed only of the detritus of mollusc shells (different levels of Wells 8z; 9; 6). All these foraminiferal assemblages as well as mollusc assemblages have different and irregular positions in the Konkian deposits of the various wells. A similar sequence of such assemblages was found in the Konkian sections of shallow-water deposits in other areas of the Northern Black Sea Region (Hladkivka Formation, Novokakhovka Formation) and in the Crimean Peninsula (Mek- enziev Strata, Tarkhankut Formation, Novokakhovka Formation) (e.g. DIDKOVSKIY, 1959; BARG, 1969, 2008; IVANOVA, 2012; VERNYHOROVA, 2015b, 2016, etc.).

The distribution of Konkian foraminiferal assemblages in more deep-water deposits of the Kerch Peninsula is significantly different from deposits of the coeval shallow-water sediments of the Northern Black Sea Region and the Crimean Peninsula. The lower and much thicker part of these deposits contains a normalmarine foraminiferal assemblage with a predominance of stenohaline species (Figs. 7, 8). A significant rearrangement of the species composition is observed only in the upper part of the Konkian deposits below the Konkian/Sarmatian boundary. These deposits contain a depleted foraminiferal assemblage with a predominance of euryhaline species and a minor admixture of the early Sarmatian species. The Kerch foraminiferal assemblages are similar to those from the relatively deep-water Konkian sediments of the Taman Peninsula and the Western Ciscaucasus (e.g. BOGDANOWICZ, 1965; GOLOVINA et al., 2009; VERNIGOROVA et al., 2006; POPOV et al., 2016; PALCU et al., 2017).

The analysis of foraminiferal assemblages with different species composition and palaeoecological characteristics revealed a common assemblage (NM1) in three Wells $(8 z ; 9 ; 6)$ of the Eastern Black Sea Region (Figs.7; 8). Marine molluscs, bryozoans and echinoid radiole were also found together with this assemblage. Small distances between these Wells (43 and $17 \mathrm{~km}$ accordingly - see Fig. 6) allow consideration of these deposits with identical fauna as an isochronous level. This level was used as a benchmark for stratigraphic correlation, for identification of hiatuses and also for the reconstruction of palaeoenvironmental conditions during Konkian time in the research area. Namely, if we assume that the HM1 assemblage in different Wells was formed 
contemporaneously then deposits with this assemblage represent a single biostratigraphic level and a marker for the stratigraphic evaluation of other horizons.

The final phase of development of the Konkian basin was determined in the upper part of Well 8z (the Eastern Black Sea Region) and Well 20 (the Kerch Peninsula) (Figs. 7, 8) based on the presence of the special foraminiferal assemblage (EH2) in these deposits.

Combining the data on changes of foraminiferal and molluscs assemblages with other bio- and lithostratigraphic data concerning the middle Miocene sediments of the investigated area (e.g. ARKHANGUELSKY, ed., 1940; DIDKOVSKIY, 1959; MOLYAVKO, 1960; BARG, 1969, 2008; PRISYAZHNYUK et al., 2007; VERNIGOROVA, 2008, 2009, 2012; VERNIGOROVA et al., 2009; VERNYHOROVA, 2015b; 2016) allowed the creation of palaeoecological and stratigraphic reconstruction of the middle Miocene sediments in the Eastern Black Sea Region (Fig. 9).

\section{CONCLUSIONS}

The study of spatial and temporal changes of foraminiferal assemblages in the Konkian deposits of Southern Ukraine indicate that the shallow-water basin of the Eastern Black Sea Region and the more deep-water basin of the Kerch Peninsula had different models of development during most of the Konkian period.

Two foraminiferal assemblages with different palaeoecological characteristics in the studied deposits of the Kerch Peninsula indicate two successive development phases of the relatively deep-water Konkian basin of this area. During the first, longer part of the Konkian, relatively stable marine conditions predominated, while the late period of existence of this palaeobasin is characterized by a sharp change to euryhaline conditions. Changes in foraminiferal assemblages in relatively deeper-water Konkian deposits of the Kerch Peninsula and the Ciscaucasus are similar. This indicates that basins with such types of sediments in the Eastern Paratethys had a similar pattern of development during the Konkian.

Many irregular vertical and lateral changes of foraminiferal assemblages with different palaeoecological characteristics and hiatuses observed in the shallow-water Konkian deposits of the Eastern Black Sea Region indicate that the palaeobasin in this area was influenced by frequent and abrupt changes in environmental conditions during most of the Konkian. Palaeoecological and lithological characteristics of the Konkian deposits of the Eastern Black Sea region are similar to those of other shallow-water coeval deposits of the Southern Ukraine, and it can be concluded that the development of the entire Northern Black Sea Region and most of the Crimean Peninsula were similar during this time period.

The late development phase of the Konkian was the same in both shallow-water deposits of the Eastern Black See region and more deep-water deposits of the Kerch Peninsula deposits. This phase was characterized by the presence of similar euryhaline assemblages of Konkian foraminifera (and molluscs) with a small admixture of the Early Sarmatian species.

\section{ACKNOWLEDGMENT}

Many thanks to V.A. PRYSYAJNYUK and O. ANISTRATENKO (IGS NAS of Ukraine, Kyiv, Ukraine) for helping in the identification of species of some molluscs; I.L. KNYAZKOVA (geologist, Volnovakha, Ukraine), L.A. FIKOLINA (geologist, Simferopol, Ukraine), for helping with the lithological description of the wells; T. RYABOKON (IGS NAS of Ukraine, Kyiv, Ukraine) A. BRATISHKO (Luhansk Taras Shevchenko National University, Starobelsk, Ukraine) for discussion of some scientific issues.

\section{REFERENCES}

ANDRUSOV, N.I. (1917): Konskiy gorizont (foladovie plasty) [Konkian horizon (Pholada beds) - in Russian].- Proceedings of the Geological and Mineralogical Museum, 2/II, 167-261.

ARKHANGUELSKY, A.D., BLOHIN, A.A., MENNER, V.V., OSIPOV, S.S., SOKOLOV, M.I. \& CHEPIKOV, K.R. (1930): Kratkiy ocherk geologicheskogo stroyeniya i neftyanykh mestorozhdeniy Kerchenskogo poluostrova [Brief sketch of the geological structure and oil fields of the Kerch Peninsula - in Russian].-Proceedings of the Main of geological exploration, 13, $142 \mathrm{p}$.

ARKHANGUELSKY, A.D. (ed.) (1940): Stratyhrafiya SSSR. T. XII. Neohen SSSR [Stratigraphy of USSR. Vol. 10. Neogene of the USSR - in Russian].--Moskow, Leningrad, $688 \mathrm{p}$.

BARG, I.M. (1969): Ervilievye i Foladovye kompleksy v sredne-miotsenovykh otlozheniyakh Yuzhnoi Ukrainy [Ervilia and Pholas assemblages in the Middle Miocene deposits of the Southern Ukraine - in Russian].- Bulletin of Moscow Society of Naturalists. Geological series, 4/23, 78-83.

BARG, I.M. (1993): Biostratigrafiya verkhnego kaynozoya Yuzhnoy Ukrainy [Biostratigraphy of the Upper Cenozoic of the Southern Ukraine - in Russian].- Dnepropetrovsk, Edition by DGU, $196 \mathrm{p}$.

BARG I.M. (2008): O pravomochnosti ispolzovaniya stratigraficheskikh terminov "Varnenskiye" i "Karvelskiye" sloi v konkskom regioyaruse Vostochnoho Paratetisa [Appropriate use of the stratigraphical terms "Varna Beds" and "Karvel Beds" in the Konkian regional stage of the Eastern Parathetys - in Russian].- Collection of the Institute of Geological Sciences of NAS of Ukraine, Kyiv, 437-442.

BARG, I.M. \& IVANOVA, T.A. (2000): Stratigrafiya i geologicheskoye razvitiye Ravninnogo Kryma v miotsene [Stratigraphy and geological development of the Crimea in the Miocene - in Russian].- Stratigraphy. Geological Correlation, 8/3, 83-93.

BARG, I.M. \& STEPANIAK, Y.D. (2003): Stratigrafiya i geologicheskoye razvitiye Ravninnogo Kryma i Kerchenskogo poluostrova v miotsenovuyu epokhu [Stratigraphy and geological development of the Crimea and Kerch peninsula in the Miocene epoch - in Russian].- Dnepropetrovsk, 170 p.

BOGDANOWICZ, A.K. (1952): Miliolody i Peneroplidy [Miliolidae and Peneropliidaein Russian].- Proceedings of VNIGRI, 64, 338 p.

BOGDANOWICZ, A.K. (1965): Stratigraficheskoe i fatsialnoe raspredelenie foraminifer v miotsene Zapadnoho Predkavkaz'ya i voprosy ikh genezisa [Stratigraphic and facies distribution of foraminifera in the Miocene of Western Ciscaucasia and questions of their genesis - in Russian]. - Proceedings of the Krasnodar branch of the All-Union Oil and Gas Research Institute, 16, 300-350.

BONDAR, O.V. (2004): Stratyhrafyya konkskykh otlozhenyy Yuzhnoy Ukrayny po ostrakodam [Stratigraphy The Konkian deposits of Southern Ukraine according to ostra$\operatorname{cods}$ - in Russian].- Problems of Phanerozoic stratigraphy of Ukraine: Scientific Papers of the Institute of Geological Sciences of Ukraine, Kyiv, 172-174.

BRATISHKO, A., SCHWARZHANS, W., REICHENBACHER, B., VERNYHOROVA, Y. \& CORIĆ, S. (2015): Fish otoliths from the Konkian (Miocene, early Serravallian) of Mangyshlak (Kazakhstan) - testimony of an early endemic evolution in the Eastern Paratethys.- Palaontologische Zeitschrift, 89/4, 839-889. doi: 10.1007/s12542-0150274-4

BUGROVA, E.M., GLADKOV, V.I., DMITRIEVA, T.V., NEVZOROVA, L.S. \& SOKOLOV, B.C. (2005): Prakticheskoe rukovodstvo po mikrofaune, Tom 8: Foraminifery kainozoya [Guidebook of microfauna, Volume 8: Cenozoic Foraminifera - in Russian]. - Proceedings of VSEGEI, $324 \mathrm{p}$.

BULEISHVILI, D.A. (1960): Geologiya i neftegazonosnost mezhgornoy vpadiny vostochnoy Gruzii [Geology and Petroleum the intermountain depressions in Eastern Georgia - in Russian].- Gostoptehizdat, Moskow, 240 p.

BURIAK, V.N. (1965): O stratigraficheskom podrazdelenii neogenovykh otlozheniy Zapadnogo Predkavkaz'ya [About stratigraphic subdivisions of Neogene sediments of the Western Ciscaucasia - in Russian].- Proceedings of KFVNII, 16, 300-350.

CHIKOVANI, A.A. (1964): Sredniy miotsen. Geologiya SSSR. Gruzinskaya SSSR. Geologicheskoye opisaniye. Tom 10 [Middle Miocene. Geology of the USSR. Georgian Soviet Union. Geological description. Volume 10 - in Russian].- Nedra, Moskow, $1 / 10,655 \mathrm{p}$.

DIDKOVSKIY, V.Ya. (1959): Pro mikrofaunu vidkladiv konkskoho horyzontu URSR, [About microfauna from deposits of the Konkian horizon of UkrSSR - in Ukrainian].Reports of the Academy of Sciences of the USSR, 4, 412-416.

DIDKOVSKIY, V.Y. \& KULICHENKO, V.G. (eds.) (1975): Stratyhrafiya URSR. T. 10. Neohen [Stratigraphy of UkrSSR. Vol. 10. Neogene - in Ukrainian].- Naukova dumka, Kyiv, 270 p.

DJANELIDZE, O.I. (1970): Foraminifery nizhnego i srednego miotsena Gruzii [Foraminifera from the Late and Middle Miocene of Georgia - in Russian].- Metsniereba, Tbilisi, $172 \mathrm{p}$.

GOZHYK, P.F. (ed.) (2012): Stratyhrafichnyy kodeks Ukrayiny [Stratigraphic Code of Ukraine - in Ukrainian].- Kyiv, $66 \mathrm{p}$.

GOLOVINA, L.A., VERNIGOROVA, Yu.V. \& BELUZHENKO, E.V. (2009): Novyye dannyye po mikropaleontologii konkskikh otlozheniy Zapadnogo Predkavkazya [New data about micropaleontology from the Konkian deposits of Western Ciscaucasia - in Russian].-Fossil flora and fauna of Ukraine: paleontological and stratigraphic aspects: proceeding of the Institute of Geological Sciences of the NAS of Ukraine, Kyiv, $311-321$. 
HILGEN, F.J., LOURENS, L.J., VAN DAM, J.A., BEU, A.G., BOYES, A.F., COOPER, R.A., KRIJGSMAN, W., OGG, J.G., PILLER, W.E. \& WILSON, D.S. (2012): The Neogene Period. The Geologic Time Scale, 1-2, 923-978. doi: 10.1016/B978-0444-59425-9.00029-9

ILYINA, L.B. (1993): Opredelitel morskih srednemiotsenovih gastropod Yugo-Zapadnoy Evrasii [Handbook for identification of the marine Middle Miocene gastropods of Southwestern Eurasia - in Russian].- Proceedings of the Paleontological Institute, 255, 1-151.

ILYINA, L.B. (2000): On the regional Konkian stage (Middle Miocene) in the Eastern Paratethys.- Stratigraphy. Geological Correlation, 8/4, 59-64.

IVANOVA, T.A. (2012): Foraminifery konkskogo regioyarusa Yuzhnoy Ukrainy: etapnos razvitiya, stratigraficheskoye znacheniye [Foraminifera from the Konkian regional stage of Southern Ukraine: Stages of evolution, stratigraphic significance - in Russian].- Proceedings of the 34th session of the Paleontological Society of NAS of Ukraine, Kyiv, 95-96.

KOIAVA, K., MOSAR, J., KVALIASHVILI, L. \& MAUVILLY, J. (2016): About Konkian Sarmatian Boundary of Georgia Based on foraminifera.- Swiss Geoscience Meeting: Platform Geosciences, Swiss Academy of Science, SCNAT, 224-225.

KRASHENINNIKOV, V.A. (1959): Foraminifery. [Foraminifera - in Russian].- In: ZHIZHCHENKO, B.P. (ed.): Atlas of the Middle Miocene fauna from North Caucasus and Crimea - Gostoptehizdat, Moskow, 15-103.

KRASHENINNIKOV, V.A., BASOV, I.A. \& GOLOVINA, L.A. (2003): Vostochnyy Paratetis: Tarkhanskiy i Konkskiy regioyarusy [The Eastern Paratethys: Tarkhanian and Konkian regional stages - in Russian].- Nauchnyy mir, Moskow, 193 p.

LIVEROVSKAYA, E.V. (1935): Fauna konkskogo gorizonta gory Dubrovoy (Severnyy Kavkaz) [Fauna of the Konkian horizon of mountains Dubrovaya (North Caucasus) in Russian].- Proceedings of Petroleum Geological Prospecting Institute, A/34, 35 p.

LIVEROVSKAYA, E.V.(1960): Tretichnyye otlozheniya Mangyshlaka [Tertiary sediments of Mangyshlak - in Russian].- Gostoptehizdat, Moskow, 142 p.

MAISSURADZE, L., KOIAVA, K., KVALIASHVILI, L. \& SPEZZAFERRI, S. (2014): Biodiversity, evolution and biostratigrafic significance of Konkian foraminifers of Euxine-Caspian basin of Eastern Paratethys.- Proceedings of the Georgian National Museum, Natural Sciences and Prehistory Section, 6, 9-22.

MERKLIN, R.L. (1953): Etapy razvitia konkskogo basseina v miocene na uge SSSR [The stages of Konkian basin development in the Miocene of the Southern USSR - in Russian].- Bulletin of the Moscow Society for the Sources of Nature, Department of Geology, 28/3, 89-91.

MOLYAVKO, G.I. (1960): Neohen pivdnya Ukrayiny [Neogene of the South of Ukrainein Ukrainian], Edition of AN URSR, Kyiv, 208 p.

MURATOV, M.V. \& NEVESSKAYA, L.A. (eds.) (1986): Stratigrafia SSSR. Neogenovaya sistema. Polutom 1 [Stratigraphy of the USSR. Neogene system. Semivolume 1 - in Russian].- Nedra, Moskva, 419 p.

NEVESSKAYA, L.A., GONCHAROVA, I.A., PARAMONOVA, N.P., POPOV, S.V., BABAK, E.V., BAGDASARYAN, K.G. \& VORONINA, A.A. (1993): Opredelitel miotsenovih dvustvorchatih molluskov Yugo-Zapadnoy Evrazii [Handbook for identifcation of the Bivalvia of Southwestern Eurasia - in Russian].- Proceedings of the Paleontological Institute, 247, $412 \mathrm{p}$.

NEVESSKAYA, L.A., KOVALENKO, E.I., BELUZHENKO, E.V. POPOV, S.V., GONCHAROVA, I.A., DANUKALOVA, G.A., ZHIDOVINOV, Y.Ya., ZAITSEV, A.V., ZASTROZHNOV, A.C., PINCHUK, T.N., ILLINA, L.B., PARAMONOVA, N.P., PISMENNAYA, N.S. \& HONDKARIAN, S.O. (2005): Regionalnaya stratigraficheskaya skhema neogena yuga yevropeyskoy chasti Rossii. [Regional stratigraphic scheme of the Neogene of the Southern European part of Russia - in Russian].Stratigrafiya, regionalnaya geologiya i tektonika, Moskow, 47-59.

NOSOVSKIY, M.F. (1960): Stratigrafiya mezokaynozoyskikh otlozheniy Belozerskogo zhelezorudnogo mestorozhdeniya (USSR) [Stratigraphy of Mesozoic-Cenozoic sediments from Belozersky iron ore deposits (Ukraine) - in Russian].- Geology and mineralogy of sedimental formations of the Ukrainian SSR. Scientific Notes of Dnepropetrovsk University, 59, 73-90.

OSIPOV, S.S. (1927): O konkskom gorizonte Severnogo Kavkaza i Kerchenskogo poluostrova [About the Konkian horizon of the North Caucasus and the Kerch Peninsulain Russian].- Bulletin of the Moscow Society of Naturalists. Department of Geology, 5/3-4. New series, 35, 371-376.

PALCU, D.V., GOLOVINA, L.A., VERNYHOROVA, Y.V., POPOV, S.V. \& KRIJGSMAN, W. (2017): Middle Miocene paleoenvironmental crises in Central Eurasia caused by changes in marine gateway configuration.- Global and Planetary Change, 158, 57-71. Doi: 10.1016/j.gloplacha.2017.09.013

PERYT, T.M. (2006): The beginning, development and termination of the Middle Miocene Badenian salinity crisis in Central Paratethys.- Sedimentary Geology, 188, 379-396. doi:10.1016/j.sedgeo.2006.03.014

POPOV, S.V., ROSTOVTSEVA, Yu.V., FILLIPPOVA, N.Yu., GOLOVINA, L.A., RADIONOVA, E.P., GONCHAROVA, I.A., VERNYHOROVA, Yu.V., DYKAN, N.I., PINCHUK, T.N., ILJINA, L.B., KOROMYSLOVA, A.V., KOZYRENKO, T.M., NIKOLAEVA, I.A. \& VISKOVA, L.A. (2016): Paleontology and stratigraphy of the Middle - Upper Miocene of Taman Peninsula. Part 1. Description of key-sections and benthic fossil groups.- Paleontological journal, (Supplement), 50/10, 168 p. doi: $10.1134 /$ S0031030116100014

PRISYAZHNYUK, V.A., KOVALENKO, V.A.\& LYULEVA, S.A. (2007): O konkskykh otlozhenyyakh yuga Ukrainy [About the Konkian sediments of the Southern Ukraine -in Russian].- Paleontological research in Ukraine: history, current state and perspectives, Kyiv, 298-305.

SOKOLOW, N. (1899): Sloi s Venus konkensis na reke Konke [Venus konkensis beds at the Konka River - in Russian].- Memores du comite geologique, 9/5, 1-96.

STARIN, D.A. (2012): Osobennosti stratigraficheskogo deleniya konkskogo regioyarusa Borisfenskogo zaliva (Yuzhnaya Ukraina) po faune mollyuskov [Features of stratigraphy the Konkian regional stage of Borysthenian Bay (Southern Ukraine) according to fauna of molluscs - in Russian].- Proceedings of the 34th session of the Paleontological Society of NAS of Ukraine, Kyiv, 99-100.

SUDO, M.M. (1961): Ob etapakh razvitiya karaganskogo basseyna i obyeme karaganskogo gorizonta [About the stages of development of the Karaganian basin and the volume of the Karaganian horizon - in Russian]. - Reports of the Academy of Sciences of the USSR, 139/6, 1442-1444.

TESLENKO, Yu.V. (ed.) (1997): Stratyhrafichnyy kodeks Ukrayiny [Stratigraphic Code of Ukraine - in Ukrainian].- Kyiv, 39 p.

VARENTSOV, M.I. (1950): Geologicheskoe stroenie zapadnoi chasti Kurinskoi depressii [Geological Structure of the Western Part of the Kura Depression - in Russian].Akad. Nauk SSSR, Moscow-Leningrad, $258 \mathrm{p}$

VERESHAGIN, V.N. \& MIRONOVA, L.V. (1982): Stratigraficheskiy slovar SSSR. Paleogen, Neogen, Chetvertichnaya sistema [Stratigraphic dictionary of the USSR. Paleogene, Neogene, Quaternary - in Russian].- Nedra, Leningrad, $616 \mathrm{p}$

VERNIGOROVA, Yu.V. (2008): Osobennosti raspredeleniya foraminifer i nekotoryye voprosy stratigrafii konkskikh otlozheniy Severnogo Prichernomor'ya [The distribution of foraminifers and some problems of stratigraphy the Konkskian deposits of the Northern Black Sea Coast - in Russian].- Biostratigraphic fundamentals of creating the stratigraphic schemes of the fanerozoic of Ukraine, Kyiv, 212-219.

VERNIGOROVA, J.V. (2009): Karagansky i konksky regioyarusi Vostochnogo Paratetisa: voprosi ih obyoma i stratigraficheskoy samostoyatelnosti [The Karaganian and Konkian regional stages of the Eastern Paratethys: problems of their stratigraphic range and validity - in Russian].- Geologichniy zhurnal, 2, 34-47.

VERNIGOROVA, Yu.V. (2012): Raspredeleniye foraminifer i mollyuskov v konkskikh otlozheniyakh Vostochnogo Prichernomoriya [Distribution of foraminifera and molluscs in the Konkian sediments of the Eastern Black Sea region - in Russian].- Proceedings of the 34th session of the Paleontological Society of NAS of Ukraine, Kyiv, 97-98.

VERNIGOROVA, Yu.V., GOLOVINA, L.A.\& GONCHAROVA, I.A. (2006): K kharakteristike konkskykh otlozheniy Tamanskoho poluostrova [The characterization of the Konkian sediments of the Taman Peninsula - in Russian].- Problems of paleontology and biostratigraphy Proterozoic and Phanerozoic of Ukraine: Scientific Papers of IGS NAS of Ukraine, Kyiv, 231-242.

VERNIGOROVA, Yu.V., KNYAZKOVA, I.L. \& KOVALENKO, V.A. (2009): Razrez miotsena Severnogo borta Prichernomorskoy vpadiny [The Miocene Section of the Northern edge of the Black Sea depression - in Russian].-Geological Journal, 3/328, 41-50.

VERNIGOROVA, Yu.V., FIKOLINA L.A. \& OBSHARSKAYA N.N. (2012): Strukturnofatsialnoye rayonirovaniye neogenovykh otlozheniy Kerchenskogo poluostrova [Structural and facies zonation of the Neogene sediments of the Kerch Peninsula - in Russian].- Geological journal, 3, 74-94.

VERNYHOROVA, Yu.V. (2014): Lito- i biofatsialniye osoblyvosti neohenovykh vidkladiv Kerchenskoho pivostrova [Lytho- and biofacies features of the Neogene deposits of the Kerch Peninsula - in Ukrainian].- Collection of scientific work of the Institute of Geological Sciences of NAS of Ukraine, 7, 126-171.

VERNYHOROVA, Yu.V. (2015a): Kriterii stratigraficheskogo raschleneniya konkskikh otlozheniy Vostochnogo Paratetisa po mollyuskam i foraminiferam [The criteria of the Konkian deposits stratigraphy of the Eastern Paratethys based on molluscs and foraminifera - in Russian].- Geological journal, 4, 77-86.

VERNYHOROVA, Yu.V. (2015b): Stratyhrafichna skhema neohenovykh vidkladiv Prychornomoriya ta prylehloyi chastyny Ukrayinskoho Shchyta [Stratigraphic scheme for the Neogene deposits of the Nothern Black sea region and adjacent part of the Ukrainian Shield - in Ukrainian].--Geology and Ore Content of Ukraine, 1/1, 81-124. doi: $10.15421 / 121510$

VERNYHOROVA, Yu.V. (2016): Stratyhrafichna skhema neohenovykh vidkladiv Kryms'koho pivostrova [Stratigraphic scheme for the Neogene deposits of the Crimea Peninsula - In Ukrainian].- Geology and Ore Content of Ukraine, 2/1, 59-106. doi: $10.15421 / 121606$

ZHAMOIDA, A.I. (ed.), (1977): Stratigraphicheskiy Kodeks SSSR [Stratigraphic Code of the USSR - in Russian].- Leningrad, $80 \mathrm{p}$.

ZHGENTI, E.M. (1976): Lyutetsiidy srednego miotsena, ikh evolyutsiya i stratigraficheskoye znacheniye [Middle Miocene Luteciidae, Their Evolution and Stratigraphic Significance - in Russian].- Metsniereba, Tbilisi, 177 p.

ZHGENTI, E.M. \& MAISSURADZE, L.S. (2016): Karaganskiy, Kartvekmskiy i Konkskiy regioyarusy Gruzii. Istoriya razvitiya molluskov i foraminifera i ikh stratigrafocheskoe znachenie [The Karaganian, Kartvelian and Konkian Deposits of Georgia. The History of Development and Stratigraphical Significans of Molluscs and Foraminifera - in Russian].- Tbilisi, 91 p.

ZHIZHCHENKO, B.P. (1937a): O vozraste i faune foladovykh sloyev [About the age and fauna of Folada bads - in Russian].- Materials of the Miocene of the northern Caucasus, 6/1, 81-117.

ZHIZHCHENKO, B.P. (1937b): K izucheniyu fatsiy 2-go sredizemnomorskogo yarusa [To study the facies of the 2nd of the Mediterranean stage - in Russian].- Materials of the Miocene of the northern Caucasus, 6/1, 133-200. 